\title{
Neuroendocrine cell populations in normal human lungs: a quantitative study
}

\author{
JOHN R GOSNEY, M C J SISSONS, R O ALLIBONE \\ From the Department of Pathology, University of Liverpool
}

ABSTRACT Pulmonary neuroendocrine cells, identified by their positive immunochemical reaction for neurone specific enolase, were readily demonstrable and uniformly distributed in 15 pairs of $\vec{\infty}$ normal adult human lungs. About $65 \%$ contained gastrin releasing peptide and nearly all the rest contained calcitonin. Leucine-enkephalin was not found. Serotonin containing cells were few, and 0 cells immunoreactive for adrenocorticotrophin and antidiuretic hormone were absent. About one in 10 cells was argyrophilic, and costorage of peptides was not seen.

\section{Introduction}

Pulmonary neuroendocrine cells in normal subjects are thought to contain the three peptides calcitonin, ${ }^{\prime}$ gastrin releasing peptide (the mammalian analogue of bombesin), ${ }^{2}$ and leucine-enkephalin, ${ }^{3}$ and the amine 5-hydroxytryptamine (5-HT; serotonin). ${ }^{4}$ These cells may be solitary ${ }^{5}$ or form clusters, ${ }^{6}$ which are termed neuroepithelial bodies ${ }^{7}$ if innervated. Because of their sparsity and lack of quantitative data on their distribution, and because many different methods have been used to identify them, misconceptions have arisen about the cells and basic questions about their function remain unanswered. Moreover, despite accumulating evidence to the contrary, ${ }^{8}$ there is a widely held belief that their role is largely confined to fetal and neonatal life, and that in the adult they are of little importance.

We have previously reported finding a remarkably uniform number and distribution of calcitonin containing cells in normal adults. ${ }^{9}$ The aim of the present study was to quantify further the population of pulmonary endocrine cells according to their content of peptide or amine, and to relate peptide or amine content to argyrophilia and positive staining for neurone specific enolase, a marker for neuroendocrine cells. ${ }^{10}$ In addition, we have sought the presence within these cells of adrenocorticotrophin (ACTH) and antidiuretic hormone (arginine-vasopressin). These two peptides have not been described in normal lungs

Address for reprint requests: Dr JR Gosney, University Department of Pathology, Duncan Building, Royal Liverpool Hospital, Liverpool L7 8XP.

Accepted 18 August 1988 but are frequently secreted by bronchial neuroendocrine neoplasms and by pulmonary tissue affected $\vec{\oplus}$ by inflammatory disease..$^{11-13}$

\section{Methods}

Details of the immunolabelling and quantification of neuroendocrine cells have been given previously. $\stackrel{\circ}{\Phi}$ Material was obtained from 15 adults with no evidence $\stackrel{\varrho}{\rightleftharpoons}$ of any appreciable pulmonary disease coming to necropsy within 18 hours of death. Seven were female $\frac{3}{5}$ and eight male, and the mean age was 75 years. The lungs were distended with Bouin's solution via the trachea, and fixed for 24 hours. About 90 blocks were taken from each pair of lungs, from the mid trachea to the subpleural parenchyma.

Adjacent sections were cut from paraffin wax blocks and antigens detected by the peroxidase-anti- $\hat{\rho}$ peroxidase method. ${ }^{14}$ Sources and dilutions of all primary antisera are shown in table 1 together with ${ }_{\circ}$ control tissues used. Incubation was for 18 hours at $4^{\circ} \mathrm{C}$. Liquid phase absorption studies were performed $\frac{7}{2}$ in which increasing amounts of antigen were added to $1 \mathrm{ml}$ aliquots of each of the antisera used. Addition of $\widetilde{N}$ the appropriate antigen in concentrations of non greater than $30.87 \mathrm{nmol}$ (gastrin releasing peptide), N $14.63 \mathrm{nmol}$ (calcitonin), $89.99 \mathrm{nmol}$ (leu-enkephalin), $\sigma$ $17.04 \mathrm{nmol}^{(a d r e n o c o r t i c o t r o p h i n}{ }^{1-24}$ ) and $46.11 \mathrm{nmol}^{-}$ (antidiuretic hormone) quenched staining when tested? on tissue sections, but the addition of other antigens at $\stackrel{D}{\$}$ concentrations up to $61.73 \mu \mathrm{mol}$ (gastrin releasing peptide), $29.26 \mu \mathrm{mol}$ (calcitonin), $179.90 \mu \mathrm{mol}$ (leu- $\overline{0}$ enkephalin), $34.09 \mu \mathrm{mol}$ (adrenocorticotrophin ${ }^{1-24}$ ) and $92.22 \mu \mathrm{mol}$ (antidiuretic hormone) had no effect. The primary antiserum was linked to rabbit immuno- 
globulin peroxidase-antiperoxidase complex diluted 1:100 by swine anti-rabbit serum diluted 1:50. The chromogen used was 3-amino 9-ethylcarbazole. All solutions were diluted in phosphate buffered saline at a $\mathrm{pH}$ of $7 \cdot 2$. Pretreatment of sections with $1 \% \mathrm{w} / \mathrm{v}$ hydrogen peroxide in methanol for 30 minutes and non-immune swine serum for 20 minutes diminished false positive staining by endogenous peroxidase and non-specific binding of immunoglobulin. The procedures were controlled by omitting each step of the procedure in turn. Adjacent sections were stained with haematoxylin and eosin and by the method of Grimelius ${ }^{15}$ for argyrophilia.

Sections were examined with a microscope fitted with a linear eyepiece graticule. At a magnification of $\times 400$ the total number of airway epithelial cells contained between the extremities of the linear graticule was counted, wherever possible at three sites for each airway cross section. After calibration with a stage micrometer the total number of epithelial cells per unit length of epithelium was calculated. The number and position of endocrine cells immunoreactive for each antigen in airways and parenchyma were noted.

By means of a Zeiss projecting microscope each section was projected on to a large sheet of paper and a tracing made of all airways, vessels, and parenchyma. Magnification was determined by projecting on to the paper the image of the stage micrometer. The length of the perimeter of each of the airways and the area occupied by alveoli were measured by planimetry, and the position of all immunoreactive cells was transferred to the tracing. From the data thus obtained the number of immunoreactive cells in cross sections of airways was expressed per $10 \mathrm{~cm}$ length of epithelium and per 10000 epithelial cells, and the number per square centimetre of parenchyma was calculated. In addition, their prevalence according to location in bronchi, bronchioles, or alveolar ducts and alveoli was recorded. By comparing adjacent sections the number and distribution of endocrine cells was determined according to their content of peptide or amine, and to whether or not they contained neurone specific enolase or were argyrophilic. The relationship of cells of different immunoreactivity to each other could be studied.
Table 2 Numbers of immunoreactive cells in the lungs of 15 normal human subjects

\begin{tabular}{|c|c|c|c|}
\hline $\begin{array}{l}\text { Subject } \\
\text { No. }\end{array}$ & $\begin{array}{l}\text { Neurone } \\
\text { specific enolase }\end{array}$ & $\begin{array}{l}\text { Gastrin } \\
\text { releasing peptide }\end{array}$ & Calcitonin \\
\hline 1 & \multirow{8}{*}{$\begin{array}{c}12.9(6.9)^{*} \\
4.7(2.5) \\
9.6(3.6) \\
3.4(1.5) \\
8.8(1.2) \\
4.5(0.9) \\
9.8(2.1) \\
3.7(0.8) \\
9.7(1.7) \\
3.7(0.7)\end{array}$} & \multirow{8}{*}{$\begin{array}{l}7.9(5 \cdot 1) \\
2.6(1.7) \\
4.1(1 \cdot 7) \\
1.3(0.6) \\
4.0(0.9) \\
2.3(0.7) \\
4.7(2 \cdot 1) \\
1.4(0.6) \\
6.6(0.8) \\
1.9(0 \cdot 1)\end{array}$} & \multirow{7}{*}{$\begin{array}{l}4.5(2.6) \\
1.8(1 \cdot 1) \\
4.2(2 \cdot 0) \\
1.7(0.9) \\
4.3(1 \cdot 4) \\
1.7(0.6) \\
4 \cdot 8(2 \cdot 0) \\
1.8(0.8) \\
3.8(2 \cdot 0)\end{array}$} \\
\hline 2 & & & \\
\hline & & & \\
\hline 3 & & & \\
\hline 4 & & & \\
\hline & & & \\
\hline 5 & & & \\
\hline & & & \multirow{2}{*}{$\begin{array}{l}1.5(0.8) \\
3.6(0.9)\end{array}$} \\
\hline 6 & \multirow{4}{*}{$\begin{array}{r}11.7(2.2) \\
4.0(0.8) \\
9.9(2.1) \\
3.6(0.8)\end{array}$} & \multirow{3}{*}{$\begin{array}{l}7.9(1.3) \\
2.8(0.8) \\
7.0(1.6)\end{array}$} & \\
\hline & & & $1.0(0 \cdot 2)$ \\
\hline 7 & & & $2.8(0.7)$ \\
\hline & & $2 \cdot 3(0 \cdot 7)$ & $1 \cdot 2(0 \cdot 1)$ \\
\hline 8 & $8 \cdot 8(1 \cdot 7)$ & \multirow{2}{*}{$\begin{array}{l}6.2(1.8) \\
2.0(0.7)\end{array}$} & \multirow{2}{*}{$\begin{array}{l}2.7(0.6) \\
0.9(0.1)\end{array}$} \\
\hline & $3.1(0.7)$ & & \\
\hline 9 & \multirow{2}{*}{$\begin{array}{l}9.4(1.3) \\
3.2(0.5)\end{array}$} & \multirow{2}{*}{$\begin{array}{l}6.6(0.6) \\
2.2(0.3)\end{array}$} & \multirow{2}{*}{$\begin{array}{l}2.7(0.9) \\
1.0(0.5)\end{array}$} \\
\hline & & & \\
\hline 10 & \multirow{2}{*}{$\begin{array}{l}9.4(1.9) \\
3 \cdot 1(0.6)\end{array}$} & \multirow{2}{*}{$\begin{array}{l}6.3(1.4) \\
2.0(0.4)\end{array}$} & \multirow{2}{*}{$\begin{array}{l}2.7(0.8) \\
1.0(0.2)\end{array}$} \\
\hline & & & \\
\hline 11 & \multirow{2}{*}{$\begin{array}{r}10.4(2.3) \\
3.9(1.2)\end{array}$} & \multirow{2}{*}{$\begin{array}{l}6.6(1.6) \\
2.8(1.0)\end{array}$} & \multirow{2}{*}{$\begin{array}{l}3.4(1.0) \\
1.0(0.2)\end{array}$} \\
\hline & & & \\
\hline 12 & \multirow{2}{*}{$\begin{array}{r}9.9(1.9) \\
4.0(0.7)\end{array}$} & \multirow{2}{*}{$2.6(0.3)$} & \multirow{2}{*}{$\begin{array}{l}2.7(1.0) \\
1.0(0.4)\end{array}$} \\
\hline & & & \\
\hline 13 & \multirow{2}{*}{$4.2(1.4)$} & \multirow{2}{*}{$2.6(0.8)$} & $\begin{array}{l}2.8(0.9) \\
1.0(0.2)\end{array}$ \\
\hline 14 & & & $3.5(0.8)$ \\
\hline & $5.5(1.0)$ & $\begin{array}{r}10.3(1.9) \\
3.8(0.7)\end{array}$ & $1 \cdot 3(0.4)$ \\
\hline 15 & \multirow{2}{*}{$\begin{array}{r}13.6(1 \cdot 7) \\
5.0(0.6)\end{array}$} & \multirow{2}{*}{$\begin{array}{l}9.8(1.7) \\
3.5(0.6)\end{array}$} & \multirow{2}{*}{$\begin{array}{l}3.5(0.4) \\
1.2(0.3)\end{array}$} \\
\hline & & & \\
\hline Overall & $10.5(3.0)$ & $6.9(2.5)$ & $3.5(1.4)$ \\
\hline & $4 \cdot 0(1 \cdot 2)$ & $2.4(0.9)$ & $1.3(0.6)$ \\
\hline
\end{tabular}

* The first figure of each pair is the number of immunoreactive cells per $10 \mathrm{~cm}$ of epithelial length; the second is the number per 10000 epithelial cells. Each is the mean (SD) for the five lobes of each pair of lungs.

Variances in numbers of neuroendocrine cells between subjects, between groups of anatomically equivalent lobes, and between individual lobes in the same subject were analysed by means of the $F$ test.

\section{Results}

Overall, as identified by neurone specific enolase immunoreactivity, there were 10.5 neuroendocrine cells per $10 \mathrm{~cm}$ of epithelial length and 4 per 10000 epithelial cells (table 2). In all subjects they extended from the trachea to alveolar ducts but none was seen in alveoli. Seventy two per cent were in bronchi, $24 \%$ in bronchioles (almost entirely in terminal rather than

Table 1 Sources and dilutions of antisera, and tissue controls

\begin{tabular}{llll}
\hline Antiserum to & Source & Dilution & Tissue controls \\
\hline Neurone specific enolase & DAKO Ltd, Bucks & $1: 2000$ & Human pancreas \\
Gastrin releasing peptide & Cambridge Research Biochemicals, Cambridge & $1: 4000$ & Human fetal lung \\
Calcitonin & DAKO Ltd & $1: 2000$ & Medullary carcinoma of human thyroid gland \\
Leucine-enkephalin & Cambridge Research Biochemicals & $1: 500$ & Rat adrenal medulla \\
Serotonin & ICN Biomedicals Ltd, Bucks & $1: 500$ Rat small intestine \\
Adrenocorticotrophin' ${ }^{24}$ & ICN Biomedicals Ltd & $1: 4000$ & Rat and human pituitary \\
Antidiuretic hormone & ICN Biomedicals Ltd & $1: 2000$ & Rat basal hypothalamus \\
\hline
\end{tabular}




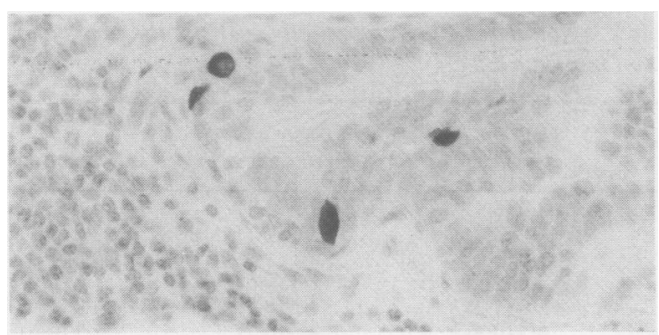

Fig 1 Four solitary endocrine cells in a terminal bronchiole showing their distribution within the airway. (Peroxidase-antiperoxidase anti-neurone specific enolase).

respiratory bronchioles), and only $4 \%$ in alveolar ducts. Nearly all were solitary: five clusters were found in five different subjects, four in terminal bronchioles, and one in an alveolar duct. The solitary cells were pyramidal or columnar in shape and basally located in the epithelium of the airway (figs 1 and 2). The clusters contained from four to eight cells each in the plane of section passing through them (fig 3).

Over half of the neuroendocrine cells contained gastrin releasing peptide (table 2) and almost all of the remainder contained calcitonin. Only 10 cells containing serotonin were seen in the whole group, all in terminal bronchioles. In a small minority $(0 \cdot 1$ cells per $10 \mathrm{~cm}$ of epithelial length, 0.3 cells per 10000$)$ no peptide or amine was detected. No cells immunoreactive for leucine enkephalin, adrenocorticotrophin, or antidiuretic hormone were found.

All cells immunoreactive for peptide or amine were also immunoreactive for neurone specific enolase, but occasional neurone specific enolase positive cells showed no reaction to any other antigen. Two of the five clusters contained calcitonin, and the remaining three gastrin releasing peptide. There was no clear evidence of co-storage of peptides, and none of the 10 solitary cells immunoreactive for serotonin contained a peptide as well. Amine and peptide content did not

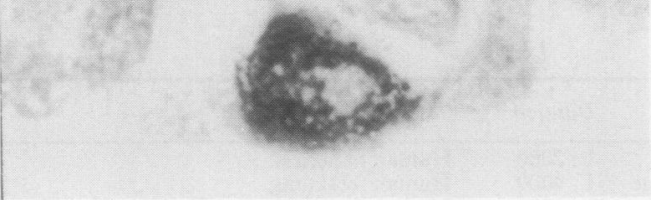

Fig 2 Typical solitary endocrine cell lying on the basement membrane of the epithelial lining of a terminal bronchiole from a normal human lung. (Peroxidaseantiperoxidase anti-neurone specific enolase).

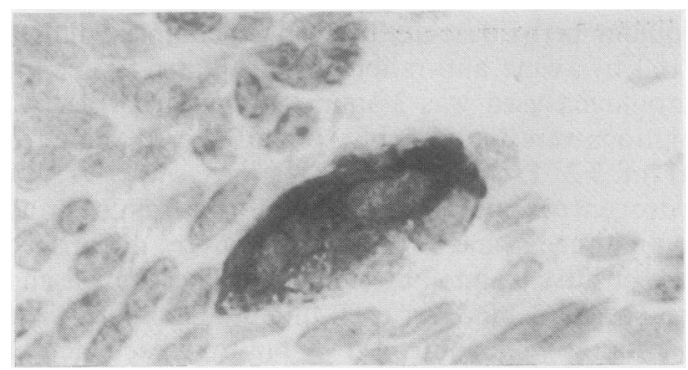

Fig 3 Cluster of endocrine cells in a terminal bronchiole from a normal human lung. Most of these are situated at points where airways branch. (Peroxidase-antiperoxidase anti-neurone specific enolase).

vary from site to site. Fewer than one in 10 solitarys cells was argyrophilic, and none of the clusters showedargyrophilia.

Analysis of variance by the $F$ test failed to show any significant variation in number between groups of equivalent lobes, either from subject to subject or from lobe to lobe in the same subject.

\section{Discussion}

In the early 1970s pulmonary neuroendocrine cells of the human fetus, neonate, and adult were showno by formaldehyde induced fluorescence to contain an amine. ${ }^{16-18}$ In rabbits the characteristics of the fluorescence strongly suggested that the amine was $\overrightarrow{\vec{O}}$ serotonin, ${ }^{4}$ and this was subsequently confirmed by 3 immunohistochemistry. ${ }^{19}$

In 1977 an unidentified peptide was detected by fluorescence spectrography in rabbit neuroepithelial bodies, ${ }^{20}$ and vasoactive intestinal peptide like sub-음 stances were found in the normal porcine lung. ${ }^{21}$ Onex year later a bombesin like substance (later shown to be을 gastrin releasing peptide) was identified in human fetal: and neonatal lungs, and localised immunohisto-ô chemically to solitary neuroendocrine cells and clusters in bronchial and bronchiolar epithelium. ${ }^{2}$ Sub-음 sequently calcitonin, leucine-enkephalin, and bom- $\rightarrow$ besin like immunoreactivity were reported in these cells in fetuses, neonates, children, and adults. ${ }^{3}$ Cells N containing the bombesin like peptide were plentiful and those containing calcitonin, although fewer, were을 also readily demonstrable. Both cell types were most $\omega$ numerous in fetal lungs. The bombesin like peptide and calcitonin were located in solitary cells ando clusters, whereas leucine-enkephalin was confined to a few solitary cells. More recently, calcitonin gene? related peptide ${ }^{22}$ has been shown to be present in neuroendocrine cells of the rat lung, ${ }^{23}$ and this sub $\frac{\text { Pे }}{\mathbb{D}}$ stance has been found in human pulmonary nerves? together with several other peptides. ${ }^{24}$

This study confirms that gastrin releasing peptided 
and calcitonin containing endocrine cells are present in adult human lungs, and shows that they comprise the great majority of the overall population as identified by neurone specific enolase immunoreactivity. This reaction, however, must be interpreted with caution. Neurone specific enolase is an established marker, ${ }^{10}$ but it does not necessarily reveal all pulmonary endocrine cells; and, on the other hand, no peptide was found in some neurone specific enolase positive cells, although a few contained serotonin. Possibly these latter elements contain a peptide we have not sought, or have failed to detect. Interestingly, leucine-enkephalin has been reported in the human lung, ${ }^{3}$ but we have failed to find it in several species. Alternatively, these cells may be depleted of their peptide content, or may be immature and "uncommitted." In neither case would immunoreactivity to neurone specific enolase be affected, as it is situated in the cytoplasm, independent of the neurosecretory granules. ${ }^{10} \mathrm{~A}$ further possibility is that leucine-enkephalin is present in the pulmonary endocrine cells only in younger individuals, and disappears with increasing age.

We have previously found that argyrophilia is an inconstant feature of pulmonary neuroendocrine cells, ${ }^{95}$ and most of those identified in the present study did not stain by the Grimelius technique. The basis of the argyrophil reaction is uncertain: ${ }^{26}$ it does not appear to depend on peptide content, and is probably related to a component of the matrix of dense core granules. In our opinion, studies based on the argyrophil reaction should be viewed with caution, although Tateishi, ${ }^{27}$ using the Bodian method, reported a distribution of neuroendocrine cells in broad agreement with ours.

Neither adrenocorticotrophin nor antidiuretic hormone could be detected. Neither substance is indigenous to the normal lung, and this study provides further evidence that they do not occur in neuroendocrine cells unless disease is present. Secretion of gastrin releasing peptide and calcitonin by bronchial neuroendocrine neoplasms clearly cannot be considered "ectopic," although it may be thought "inappropriate" and is clearly abnormal. The same may be said of the secretion of calcitonin by diseased lungs that are the seat of inflammatory disease. ${ }^{29}$ Secretion of substances such as adrenocorticotrophin and antidiuretic hormone, however, that are not detectable in either neuroendocrine cells or nerves of normal lungs is clearly both inappropriate and truly ectopic. Its mechanism remains uncertain. ${ }^{30}$

This study shows that in non-diseased lungs from human adults pulmonary neuroendocrine cells are readily and consistently demonstrable. Nearly all contain either gastrin releasing peptide or calcitonin. Although their function remains uncertain, it is difficult to imagine that such a uniform and consistent population is redundant.

We would like to thank Mrs Angela Platt-Higgins for her invaluable technical assistance, Mr A Williams for taking the photographs and Miss C Youd for processing the manuscript. The work was supported by a grant from the Mersey Regional Health Authority.

\section{References}

1 Becker KL, Monaghan KG, Silva OL. Immunocytochemical localization of calcitonin in Kulchitsky cells of human lung. Arch Pathol Lab Med 1980;104:196-8.

2 Wharton J, Polak JM, Bloom SR, et al. Bombesin-like immunoreactivity in the lung. Nature 1978;273:769-70.

3 Cutz E, Chan W, Track NS. Bombesin, calcitonin and leu-enkephalin immunoreactivity in endocrine cells of human lung. Experientia 1981;37:765-7.

4 Lauweryns JM, Cokelaere M, Theunynck P. Serotoninproducing neuroepithelial bodies in rabbit respiratory mucosa. Science 1973;180:410-3.

5 Hage E. Light and electron microscopic characteristics of the various lung endocrine cell types. Invest Cell Pathol 1980;3:345-51.

6 Fröhlich F. Die "Helle Zelle" der Bronchialschleimhaut und ihre Beziehungen zum Problem der Chemoreceptoren. Frankfurter Z Pathol 1949;60:517-59.

7 Lauweryns JM, Peuskens J. Neuro-epithelial bodies (neuroreceptor or secretory organ ?) in human infant bronchial and bronchiolar epithelium. Anat Rec 1972; 172:471-81.

8 Becker KL, Gazdar AF, eds. The endocrine lung in health and disease. Philadelphia: Saunders, 1984.

9 Gosney JR, Sissons MCJ, O'Malley AJ. Quantitative study of endocrine cells immunoreactive for calcitonin in the normal adult human lung. Thorax 1985;40: 866-9.

10 Wharton J, Polak JM, Cole GA, Marangos PJ and Pearse AGE. Neuron specific enolase as an immunocytochemical marker for the diffuse neuroendocrine system in human fetal lung. J Histochem Cytochem 1981;29: 1359-64.

11 Bryant DH. The syndrome of inappropriate secretion of anti-diuretic hormone in infectious pulmonary disease. Med J Austr 1972;i:1285-8.

12 Tsutsumi Y, Osamura RY, Watanabe K, Yanaihara N. Immunohistochemical studies on gastrin-releasing peptide and adrenocorticotropic hormone-containing cells in the human lung. Lab Invest 1983;48:623-32.

13 Abe K, Kameya T, Yamaguchi K, et al. Hormoneproducing lung cancers. In: Becker $\mathrm{KL}$, Gazdar $\mathrm{AF}$, eds. The endocrine lung in health and disease. Philadelphia: Saunders, 1984:549-95.

14 Sternberger LA. Immunocytochemistry. New York: John Wiley, 1979:104-69.

15 Grimelius $L$. The argyrophil reaction in islet cells of adult human pancreas studied with a new silver nitrate procedure. Acta Soc Med Upsal 1968;73:271-94. 
16 Lauweryns JM, Peuskens JC, Cokelaere M. Argyrophil, fluorescent and granulated (peptide and amineproducing?) /:FG cells in human infant bronchial epithelium. Light and electron microscopic studies. Life Sci 1970;9:1417-29.

17 Hage E. Endocrine cells in the bronchial mucosa of human fetuses. Acta Pathol Microbiol Scand (section A) 1972;80:225-34.

18 Hage E. Amine handling properties of the APUD cells in the bronchial epithelium of human fetuses and in the epithelium of the main bronchi of human adults. Acta Pathol Microbiol Scand (section A) 1973;81:64-70.

19 Lauweryns JM, de Bock V, Verhofstad AAJ, Steinbusch HWM. Immunohistochemical localization of serotonin in intrapulmonary neuroepithelial bodies. Cell Tissue Res 1982;226:215-23.

20 Lauweryns JM and Liebens M. Microspectrography of formaldehyde and fluorescamine-induced fluorescence in rabbit pulmonary neuroepithelial bodies: Demonstration of a new probably polypeptide intracytoplasmic substance. Experientia 1977;33:1510-1.

21 Said SI, Mutt V. Relationship of spasmogenic and smooth muscle relaxant peptide from normal lung to other vasoactive compounds. Nature 1977;265:84-5.

22 Rosenfeld MG, Mermod JJ, Amara SG, et al. Production of a novel neuropeptide encoded by the calcitonin gene via tissue-specific RNA processing. Nature 1983;304: 129-35.
23 Cadieux A, Springall DR, Mulderry PK et al. Occur- $\vec{F}$ rence, distribution and ontogeny of CGRP immunoreactivity in the rat lower respiratory tract: effect? of capsaicin treatment and surgical denervations. Neuroscience 1986;19:605-27.

24 Barnes PJ. Regulatory peptides in the respiratory system. Experientia 1987;43:832-9.

25 Gosney JR, Sissons MCJ. Widespread distribution of bronchopulmonary endocrine cells immunoreactive $\vec{O}$ for calcitonin in the lung of the normal adult rat. Thorax 1985;40:194-8.

26 Solcia E, Capella C, Buffa R. Histochemical and ultrastructural studies on the argentaffin and argyrophil $\times$ cells of the gut. In: Coupland RE, Fujita T, eds. Chromaffin, enterochromaffin and related cells. NewYork: Elsevier, 1976:209-25.

27 Tateishi R. Distribution of argyrophil cells in adult human lungs. Arch Pathol 1973;96:198-202.

28 Heath D, Smith P, Gosney J, et al. The pathology of the early and late stages of primary pulmonary hyper- tension. Br Heart J 1987;58:204-13.

29 Becker KL, Silva OL, Snider RH, et al. The pathophysiology of pulmonary calcitonin. In: Becker $\mathrm{KL}$, Gazdar AF, eds. The endocrine lung in health and disease. Philadelphia Saunders, 1984:277-300.

30 Stevens RG, Moore GF. Inadequacy of APUD conceptco in explaining production of peptide hormones byo tumours. Lancet 1983;i:118-9. 